\title{
高齢者糖尿病患者における高齢者総合的機能評価と薬剤自己管理能力との関係
}

\author{
堀川俊二, ${ }^{*}, a$ 徳本和哉, ${ }^{a}$ 要田芳代, ${ }^{a}$ 川上恵子, ${ }^{a}$ \\ 只佐宣子, ${ }^{a}$ 礒貝明彦, ${ }^{a}$ 竹増まゆみ, ${ }^{a}$ 伊東明彦 $b$
}

\section{Relation between Comprehensive-geriatric-assessment and the Ability of Self-administration in Elderly Diabetic Patients}

\author{
Shunji Horikawa, ${ }^{*, a}$ Kazuya ToKumoto,${ }^{a}$ Kayo Kanameda, ${ }^{a}$ Keiko KawaKami, ${ }^{a}$ \\ Nobuko TADASA, ${ }^{a}$ Akihiko IsogaI, ${ }^{a}$ Mayumi TAKemasu, ${ }^{a}$ and Akihiko ITO ${ }^{b}$ \\ ${ }^{a}$ Department of Pharmacy, JA Yoshida General Hospital, 3666 Yoshida Yoshida-cho, Akitakada City \\ 731-0501, Japan, and ${ }^{b}$ Department of Medicinal Therapy Research, Meiji Pharmaceutical \\ University, 2-522-1 Noshio, Kiyose City 204-8588, Japan
}

(Received March 12, 2007; Accepted August 8, 2007)

\begin{abstract}
Intellectual ability of self-administration plays a crucial role in a diabetes regimen. However, in many cases, self-administration is considered difficult, because of the impairment of activities of the individual's daily living (ADL), instrumental ADL and cognitive function. To assess comprehensive-geriatric-assessment (CGA) in elderly diabetic sufferers, 62 elderly inpatients and outpatients aged over 70 years were investigated. CGA includes Barthel index (BI), Mini-mental-state-examination (MMSE) and the Tokyo Metropolitan Institute of Gerontology index of competence (TMIGIC). The relation of ability to self-administer and CGA was examined. In oral therapy, there was significant difference between self-administration and non-self-administration in MMSE $(p=0.0065)$, BI $(p=0.0219)$ and TMIGIC $(p=0.0053)$. Among these indexes, TMIGIC was the most sensitive index in oral therapy. In insulin therapy, there was also significant difference between self-administration and non-self-administration: MMSE $(p=0.00042)$, BI $(p=$ $0.000019)$ and TMIGIC $(p=0.0019)$. Among these indexes, BI was the most sensitive index in insulin therapy. It was suggested that CGA was useful to assess the ability of self-administration in elderly diabetic patients.
\end{abstract}

Key words_—elderly; diabetes mellitus; comprehensive-geriatric-assessment

\section{緒言}

わが国の糖尿病患者数は年々増加の一途を辿つて いる. 平成 14 年に厚生労働省が実施した糖尿病実 態調査 ${ }^{1)}$ によれば「糖尿病が強く疑われる人」と 「糖尿病の可能性を否定できない人」を合わせると， 平成 9 年には 1370 万人であった人数が 1620 万人に 急増している，そしてその増加は，男女とも 60 歳 代と 70 歳代以上の高齢者における増加によるもの であり，50 歳代以下の青壮年層では減少傾向にあ る。また高齢者における増加は 70 歳代以上の男性 で「糖尿病が強く疑われる人」がほぼ倍増している. 糖尿病の頻度は加齢とともに直線的に増加し，60 歳以上では 10-15\%にまで増加する。この数值から

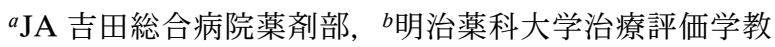
室

*e-mail: ja-ysd-pharmacy@ beach.ocn.ne.jp
}

すると，現在日本には約 300 万人の 60 歳以上の糖 尿病患者が存在するといわれている。 さらにわが国 では高齢化が進んできている，わが国の総人口は, 平成 17 年 10 月 1 日現在, 1 億 2776 万人となり, 前年（1 億 2778 万人：推計人口の遡及補正後）に 比べて 2 万人減少し，戦後では初めてマイナスに転 じた. 65 歳以上の高齢者人口は，過去最高の 2560 万人となり, 総人口に占める割合 (高齢化率) も $20.04 \%$ と，初めて $20 \%$ を超えた．高齢者人口のう ち, 前期高齢者 (65-74 歳) 人口は 1403 万人, 後 期高齢者（75 歳以上）人口は 1157 万人となってい る. JA 吉田総合病院（以下当院と略す）が位置す る広島県北部地域は高齢化先進地域であり，その高 齢化率は $32.9 \%$ あるこのような背景から高齢者 糖尿病の管理が重要な問題となっている.

慢性疾患の良好な管理のためには，疾病の治療の みならず，その後の自己管理が重要であり，高齢者 
の糖尿病治療においても, 食事療法, 運動療法, 経 口血糖降下薬，インスリン注射などの治療を継続し なければならない。しかし高齢者糖尿病患者，特に 後期高齢者では, 日常生活動作度 (Activities of Daily Living, 以下 ADL と略す）の低下, 認知機 能の低下，うつゃ不安などの精神的な問題，家族の サポートの不足などにより治療が困難となる場合が 少なくない。したがって，高齢者糖尿病患者の治療 には，若い糖尿病患者とは異なつたアプローチが求 められ，ADL，認知機能，心理状態，家族のサ ポートなどを評価する高齢者総合的機能評価 (Comprehensive-Geriatric-Assessment, 以下 CGA と略す)の必要性が報告されている. ${ }^{2)}$ そこで今回, 70 歳以上の高齢者糖尿病患者に対して CGA を行 うとともに，薬剂の自己管理能力及び血糖コント ロールとの関係について検討した.

\section{方法}

2006 年 4-8 月に当院に通院あるいは入院した 70 歳以上の高齢者糖尿病患者を対象とし, 質問紙調査 に関して説明を行い，同意が得られた患者 62 名に 対して CGA を行った。調査は面接方式で調查者が 質問表に記入した。その他の必要な情報は，診療記 録から収集し，得られた個人情報は特定の個人を識 別できないように配慮した。

CGA は，評価表を用いて以下の各項目について 行った.

1. MMSE (Mini-Mental-State Examination) $)^{3)}$ に よる認知機能の評価 30 点を満点とし, 点数が 低くなるほど認知機能が低下していることを表す。 カットオフ値は 23 点である.

\section{Barthel Index ${ }^{4)}$ による基本的 ADL の評価} 食事，排泄，歩行，入浴，更衣など身の周りの動作 を中心とする基本的 ADL を評価する. 100 点を満 点とし，点数が低くなるほど ADL が低下している ことを表す。

3. 老研式活動能力指標 5 手段的 ADL, 知的 ADL，社会的活動度を評価する. 13 点を満点と し，点数が低くなるほど活動能力が低下しているこ とを表す．カットオフ值はない．個々の状況を把握 するための参考とする.

4. 統計処理得られた結果は平均土標準偏差 で示した。群間比較には Student's $t$-test，あるいは
Mann-Whitney’s $U$ test を行った。なお統計処理に はSPSSを用いた。

\section{結果及び考察}

評価患者総数は 62 名で, 経口療法患者は 31 名, すべて入院患者であり，平均年齢 79.7 歳（70-92 歳）で約 $61 \%$ が薬剤を自己管理していた。一方， インスリン療法患者は 31 名, 外来患者 24 名, 入院 患者 7 名であった。平均年齢は，77.0 歳 (70-89 歳) で自己注射をしていた患者は約 $67 \%$ であた。経 口療法群とインスリン治療群で平均 $\mathrm{HbA}_{1 \mathrm{c}}$ 值は, それぞれ 7.3\%, 7.6\%で有意差はみられなかった (Table 1).

1. CGA における各項目の評価経口療法施 行患者の CGA の結果を各評価項目について薬剤の 管理状況別に評価点数の人数分布として Table 2 に，またインスリン療法施行患者の CGA の結果を 各評価項目について薬剤の管理状況別に評価点数の 人数分布として Table 3 に示す.

1-1. MMSE 経口療法施行患者群の評価点数 の人数分布は 22 点以上に $58 \%$ が分布し, MMSE 30 満点が $13 \%$ で，平均点数は，22.3土5.6であった。 一方，インスリン療法施行患者群では，22 点以上 に $77 \%$ が分布し，さらに MMSE30 満点が $45 \%$, 平均点数は, $24.7 \pm 6.7$ という結果であった。 茂木 ら6)の報告では，インスリン治療を受けている患者 の MMSE は, 非インスリン治療患者, 非糖尿病患 者に比べて有意に低く, 年齢 $72.8 \pm 6.3$ （歳）で $25.4 \pm 2.0$ であった。 今回の結果では，平均年齢 $77.03 \pm 6.1$ (歳) と高齢であるにも係わらず，評価 点数は，茂木ら6の報告とほぼ同等であり，インス リン療法を行っている患者群で認知機能が高かった.

1-2. Barthel Index 経口療法施行患者群の評

Table 1. Characteristics of Patients

\begin{tabular}{lccc}
\hline \hline & 経口療法 & インスリン療法 & $p$ 值 \\
\hline 患者数 & 31 & 31 & \\
年齢 (歳) & $79.7 \pm 6.8$ & $77.0 \pm 6.1$ & 0.107 \\
性別 (男 $/$ 女) & $8 / 23$ & $14 / 17$ & \\
$\mathrm{HbA}_{1 \mathrm{c}}(\%)$ & $7.3 \pm 1.3$ & $7.6 \pm 1.4$ & 0.448 \\
薬剂の管理状況 & & & \\
$\quad$ 自己管理人数 & 19 & 21 & \\
非自己管理人数 & 12 & 10 & \\
\hline
\end{tabular}


Table 2. CGA of Oral Therapy

a) Score of MMSE

\begin{tabular}{|c|c|c|c|c|c|c|c|c|}
\hline \multirow{2}{*}{ 薬剂の管理 } & \multicolumn{8}{|c|}{ 評 価 点 数 } \\
\hline & $<10$ & $10-12$ & $13-15$ & $16-18$ & $19-21$ & $22-24$ & $25-27$ & $28-30$ \\
\hline 非自己 (人) & 1 & 1 & 1 & 1 & 4 & 3 & 1 & 0 \\
\hline 自己（人） & 0 & 0 & 1 & 1 & 3 & 4 & 4 & 6 \\
\hline
\end{tabular}

b) Score of Barthel Index

\begin{tabular}{|c|c|c|c|c|c|}
\hline \multirow{2}{*}{ 薬剂の管理 } & \multicolumn{5}{|c|}{ 評 価 点 数 } \\
\hline & $<50$ & $50-70$ & $71-80$ & $81-90$ & $91-100$ \\
\hline 非自己 (人) & 4 & 2 & 2 & 2 & 2 \\
\hline 自己（人） & 1 & 4 & 1 & 2 & 11 \\
\hline
\end{tabular}

c) Score of Tokyo Metropolitan Institute of Gerontology Index of Competence

\begin{tabular}{|c|c|c|c|c|}
\hline \multirow{2}{*}{ 薬剂の管理 } & \multicolumn{4}{|c|}{ 評 価 点 数 } \\
\hline & $<5$ & $5-7$ & $8-10$ & $11-13$ \\
\hline 非自己 (人) & 8 & 1 & 1 & 2 \\
\hline 自己（人） & 3 & 2 & 3 & 11 \\
\hline
\end{tabular}

Table. 3 CGA of Insulin Therapy

a) Score of MMSE

\begin{tabular}{|c|c|c|c|c|c|c|c|c|}
\hline \multirow{2}{*}{ 薬剂の管理 } & \multicolumn{8}{|c|}{ 評 価 点 数 } \\
\hline & $<10$ & $10-12$ & $13-15$ & $16-18$ & $19-21$ & $22-24$ & $25-27$ & $28-30$ \\
\hline 非自己 (人) & 2 & 0 & 1 & 0 & 3 & 0 & 4 & 0 \\
\hline 自己（人） & 0 & 0 & 0 & 0 & 1 & 3 & 4 & 13 \\
\hline
\end{tabular}

b) Score of Barthel Index

\begin{tabular}{|c|c|c|c|c|c|}
\hline \multirow{2}{*}{ 薬剤の管理 } & \multicolumn{5}{|c|}{ 評 価 点 数 } \\
\hline & $<50$ & $50-70$ & $71-80$ & $81-90$ & $91-100$ \\
\hline 非自己 (人) & 4 & 2 & 0 & 2 & 2 \\
\hline 自己（人） & 0 & 0 & 1 & 0 & 20 \\
\hline
\end{tabular}

c) Score of Tokyo Metropolitan Institute of Gerontology Index of Competence

\begin{tabular}{lcccc}
\hline \hline \multirow{2}{*}{ 薬剤の管理 } & \multicolumn{5}{c}{ 評 } & 価 & 点 & 数 & \\
& $<5$ & $5-7$ & $8-10$ & $11-13$ \\
\hline 非自己(人) & 6 & 0 & 0 & 4 \\
自己 (人) & 1 & 0 & 1 & 19 \\
\hline
\end{tabular}

価点数の人数分布は 100 点満点が $42 \%$ あったが, 70 点以下が $31 \%$ で，平均点数は，75.1 \pm 30.6 とい う結果となった。鳥羽7) は経口糖尿病薬で治療入院 中の高齢者に行った調査によれば平均年齢 $71 \pm 0.9$
（歳）で入院時の Barthel Index は 87, 退院時には 91 であったと報告している，今回の結果は，鳥羽 の報告と比べて低い結果となった。これは平均年齢 が高いことが影響していると考えられ，得点が低い ことを考えれば服薬行動への援助が必要となる.

一方，インスリン療法施行患者群では，70 点以 下が約 $19 \%$ で，平均点数は，87.4 24.9 であっ た．特に自己注射を施行している群では，ほぼ全員 が Barthel Index100 満点であった.

Barthel Index の総得点は活動能力を示すもので あり，100 点満点であるからといって独居可能であ ることを意味しない．身体的な補助は全く受けなく ても，誰かの声がけや見守りを必要とする場合には 自立とみなされない8)場合があり，自立援助に向け た指導が重要で，退院支援では家族を含めた介護者 に服薬管理を指導する必要がある.

1-3. 老研式活動能力指標 経口療法施行患者 群の評価点数の人数分布は, 7 点以下に $45 \%$ が分布 しており，高齢，認知機能の低下などが原因として 考えられた。インスリン療法施行患者群では 13 点 満点が $48 \%, 11$ 点以上に $78 \%$ が分布した.

老研式活動能力指標は手段的 ADL - 知的 ADL · 社会的活動を評価するものである，高齢者糖尿病の 手段的 ADL 低下と関連する要因は年齢（80 歳以 上), 認知機能 (MMSE23 点以下), 視力障害, 个 ンスリン治療，糖尿病合併症が報告されている9 こ とから, MMSE, Barthel Index の結果が反映され, 経口療法施行患者群で低值を示す傾向にあった。

以上の結果から，高齢者糖尿病患者の治療におい て CGA を行うことによって問題点が抽出され，適 切な対応が可能となることが分かった.

2. CGA と薬剂管理状況の関係糖尿病の治 療及び療養指導において薬剤の自己管理が十分行え るか否かは, 治療効果にも影響し, 自己管理の可否 を評価することは非常に重要である。しかし，その 評価は, 患者の観察など治療者の経験的判断で行わ れるのが一般的であり，明確な指標は示されていな い. 前述の鳥羽は経口糖尿病薬など 7 種類強の薬剂 管理は $75 \%$ が自立しているに過ぎなかったと報告 しており，当院では約 $60 \%$ しか自立していなかつ た．そこで薬剤の自己管理の可否の判断指標の探索 を目的にCGA と薬剤管理状況の関係について検討 を行った. 
2-1. 経口療法施行患者における CGA（Table 2） いずれの評価項目についても薬剤を自己管理して いる群の評価点数が高く，自己管理をしていない群 は評価点数の低い人が多い傾向が認められた。そこ で，各評価項目について Mann-Whitney's $U$ test を 行った。その結果, MMSE $(p=0.0065)$, Barthel Index $(p=0.0219)$, 老研式活動能力指標 $(p=$ 0.0053）のいずれの評価においても両群間に有意差 が認められ，自己管理群の評価点数が高いことが分 かった.

このことからこれらの評価を行うことで経口薬剤 の自己管理の可否を判断できることが示唆された.

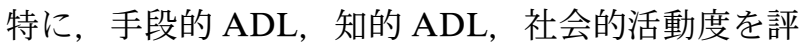
価する老研式活動能力指標による評価は，その違い が明確となり，自己管理の可否の判断により有効で あると思われた。経口療法では服用の意義，服用 量，服用時期，服用方法などの理解が自己管理を行 う上には重要となるためで，葛谷ら ${ }^{10)}$ は老年科入院 症例において，服薬コンプライアンスは CGA の各 項目とは有意な関係がなかったが，用法，薬効の理 解度との間には有意な関係があり，理解度自体は手 段的 ADL，認知機能，コミュケーション能力と関 連していたと報告している。

また，老研式活動能力指標による評価を行つた場 合，経口薬剤の自己管理の判断の分岐点は，Table 2 (c) の分布状況から 5-7 点付近にあり，これより点 数が高い場合には自己管理可能と判断できるものと 推測される。

2-2. インスリン療法施行患者における CGA （Table 3）＼cjkstart経口療法施行患者の場合と同様に自 己注射を施行している群で評価点数の高い患者が多 い傾向にあり, MMSE $(p=0.00042)$, Barthel Index $(p=0.000019)$, 老研式活動能力指標 $(p=0.0019)$ のいずれの評価においても自己注射群の評価点数が 有意に高いことが分かった。そして，インスリン療 法施行患者では，経口療法施行患者の場合と異なり， Barthel Index の評価が，インスリンの自己注射の 可否の判断により有効であると思われた. Barthel Index は食事，排泄，歩行，入浴，更衣など身の周 りの動作を中心とする基本的 ADL を評価するもの で，Barthel Index の得点が低下すると介護負担度 が増すことが明らかとなっている8)インスリンの自 己注射では，経口療法の場合と同様の患者の理解が
必要であるとともにインスリン注射の手技の理解と 施行が求められる。そのため Barthel Index が有用 となると考える.

また，Barthel Index による評価を行った場合， インスリンの自己注射の可否の判断の分岐点は, Table 3(b)の分布状況から 81-90 点付近にあり，こ れより点数が高い場合には自己注射可能と判断でき るものと推測される.

現在, 当院ではインスリン療法患者の約 $34 \%$ が 70 歳以上の後期高齢者であり, 今後，高齢者糖尿 病の急増等より高齢でのインスリン導入の増加が予 測される。薬剤師は CGA を利用して認知能力，身 体機能を熟知しインスリン自己注射のための教育を 行う必要がある.

\section{CGA と $\mathrm{HbA}_{1 \mathrm{c}}$ の関係 $\mathrm{CGA}$ が薬剂の自} 己管理に影響することが示されたことから，CGA は治療効果についても影響を及ぼすことが考えられ る。そこで血糖コントロールに及ぼす CGA の影響 について薬剤の管理状況別に検討した。

経口療法施行患者の場合，Barthel Index 及び老 研式活動能力指標については薬剤の管理状況に係わ らず $\mathrm{HbA}_{1 \mathrm{c}}$ との間に一定の関係は認められなかっ た。しかし，MMSEでは，自己管理群は $\mathrm{HbA}_{1 \mathrm{c}}$ に 影響を及ぼさなかったものの，非自己管理群で MMSE と $\mathrm{HbA}_{1 \mathrm{c}}$ との間に有意な負の相関 $\left(\mathrm{R}^{2}=\right.$ $0.612, p=0.0026)$ が認められ，MMSE による点数 が低いほど血糖コントロールが不良となることが示 唆された（Fig. 1)。これは認知機能低下により食 事療法などのコンプライアンスが低下したためと考 えられ，糖尿病治療をより困難にすることが推測さ

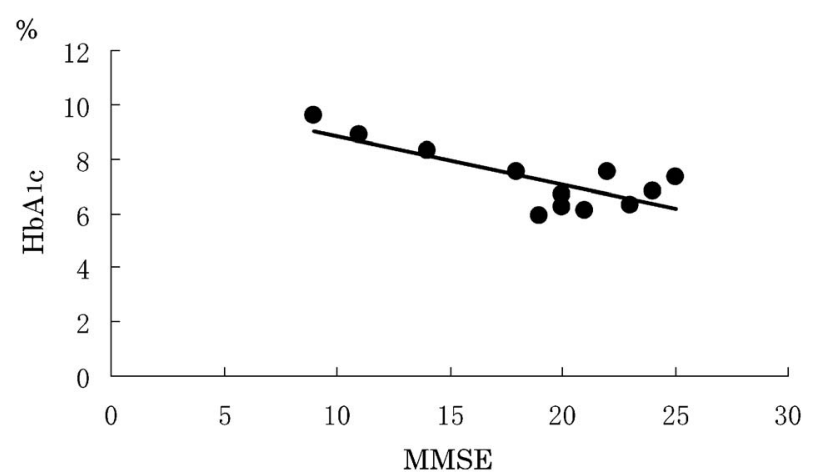

Fig. 1. Significant Negative Correlation between $\mathrm{HbA} 1 \mathrm{c}$ and MMSE in Non-self-administration Patients Receiving Oral Therapy $\left(\mathrm{R}^{2}=0.612, p=0.0026\right)$. 
れた。また老年者のコンプライアンスが認知機能 （MMSE） と関係するという報告もある. ${ }^{11)}$

一方，インスリン療法施行患者の場合には，自己 注射の状況に係わらず MMSE, Barthel Index 及び 老研式活動能力指標のいずれに関しても血糖コント ロールへの影響は認められなかった。

$$
\text { ま と め }
$$

今回の調査では, CGA は薬の自己管理が可能か 否かを判断するために有用な評価方法であることが 示唆された。 今後さらに増加する高齢者糖尿病患者 の治療において，CGA を行うことで各患者の問題 点が抽出され，薬の管理だけでなく，高齢者が抱え る様々な問題をチームアプローチによって解決して いくことが高齢者糖尿病のよりよい管理と治療につ ながると考える。

\section{REFERENCES}

1) Diabetes mellitus field study, Ministry of Health and Welfare., Health Servuce Bureau S (2004), 〈http://www.mhlw.go.jp/shingi/2004/ 03/s0318-15.html

2) Araki A., Tounyoubyou Master, 1, 400-409
(2003).

3) Mori E., Mitani Y., Yamdori S., Jpn. J. Neuropsychol., 1, 2-10 (1985).

4) Mahoney F. I, Barthel D. W., Maryland State Med. J., 14, 56-61 (1965).

5) Koyano W., Shibata H., Nakazato K., Yosiga H., Jpn. J. Public Health, 34, 109-114 (1987).

6) Mogi N., Umegaki H., Hattori A., Maeda N., Miura H., Kuzuya M., Shimokata H., Ando F., Ito H., Iguchi A., Diabetes Complications, 18 (1) : 42-46 (2004).

7) Toba K., "Koureisya-Sougouteki-kinouhyouka-guideline," Kouseikagaku-kenkyuujyo, Tokyo, 2004, pp. 46-48.

8) Toba K., "Koureisya-Sougouteki-kinouhyouka-guideline," Kouseikagaku-kenkyuujyo, Tokyo, 2004, pp. 140-144.

9) Araki A., Nakano T., Oba K., Geriatr. Gerontol. Int., 4, 2004 (in press).

10) Kuzuya M., Endou H., Umegaki H., Nakao M., Niwa T., Kumagai T., Uisita Y., Nabeshima T., Shikata H., Nippon Ronen Igakkai Zasshi, 37, 363-370 (2000).

11) Nikolaus T., Kruse W., Bach M., Eur. J. Clin. pharmacol., 49, 255-259 (1996). 